\title{
Design and Fabrication of a Modified Portable Biogas Digester for Renewable Cooking-Gas Production
}

\author{
Barinyima Nkoi, Barinadaa T. Lebele-Alawa, and Benedict Odobeatu
}

\begin{abstract}
This paper focuses on re-engineering design and fabrication of a modified potable biogas digester for the production of biogas as a renewable energy source for domestic use. Digesters used around the world are commonly big in size. There is need to modify and re-engineer an existing biogas digester to fit in to modern design for better efficiency, portability and safety. Floating drum and Flexible balloon are digesters to be modified as a thin walled pressure vessel with radius-thickness ratio $\left(\frac{r}{t}\right)$ greater than 10. ASME codes and standards were used to carry out the sizing calculations, thickness and pressure calculations for the cylindrical pressure vessel shells and also calculations for the storage tank hemisphere shell. AISI 304 (Chromium-Nickel steel) is used for the vessel shell and the maximum allowable stress was found to be $137 \mathrm{MPa}$. Weld efficiency of $85 \%$, corrosion allowance of $0.02 \mathrm{~mm}, \frac{r}{t}$ of 24 (for digester), $\frac{r}{t}$ of 18 (for collector) and $\frac{r}{t}$ of 20 (storage tank) were obtained. $17 \mathrm{~kg}$ of cow dung and $34 \mathrm{~kg}$ of water with temperature of $32^{\circ} \mathrm{C}$ were the raw materials used to produce a cumulative gas volume of $0.1243 \mathrm{~m}^{3}$ for 30 days. Furthermore, a bike pump was modified and used to increase methane gas pressure from $4.903 \mathrm{kPa}$ to $345 \mathrm{kPa}$ to suit the modern domestic gas cookers design and storage tank. Unlike other biogas plants, an electronic smoke alarm detector (model: Ei100) is placed $300 \mathrm{~mm}$ below the digester top for effective fire protection. Series of tests were performed to ensure that the constructed prototype met the desired specifications and standards. Such tests include: smoke detector test, pressure testing, gas leak test, and a unit test run. All the tests showed positive performance which confirmed that the aim of research was actually achieved. This waste-towealth as well as waste-to-energy technology would aid cheap household cooking with gas. Besides, this research has demonstrated that biogas generation could be done right in a kitchen owing to the portability of the biodigester.
\end{abstract}

Index Terms - Biodigester; Biogas; Cooking-Gas; Cow-Dung; Pressure-Vessel.

\section{INTRODUCTION}

Recent rapid increase in human population has put pressure on energy generation and utilisation all over the world. As standard of living increases in developing countries, the average consumption and need for energy has increased drastically. Thus, it has been forecasted that in a long-run, there would be a depletion of conventional energy resources and if drastic measures are not taken, there could

Published on March 17, 2018

B. Nkoi is with the Mechanical Engineering Department, Rivers State University, Port Harcourt, Nigeria (email: nkoi.barinyima@ ust.edu.ng).

B.T. Lebele-Alawa is with the Mechanical Engineering Department, Rivers State University, Port Harcourt, Nigeria (e-mail: lebelealawa@yahoo.com; lebele-alawa.thaddeus@ust.edu.ng).

B. Odobeatu is a Postgraduate student with the Mechanical Engineering Department, Rivers State University, Port Harcourt, Nigeria (e-mail: odobeatu.b@npdc-Nigeria.com). be insufficient energy available to meet the ever increasing demands by the populace. Hence, there is urgent need to seek alternative and renewable sources of sustainable energy that are environmentally friendly [1].

It has been shown that biogas is a renewable energy resource generated by bio-degradation of organic substances under anaerobic conditions [2]. It was asserted that anaerobic digestion can convert energy stored in organic matter of manures into biogas. Anaerobic digestion is a biological process whereby micro-organisms convert complex organic matter to biogas. It is found that biogas consists of about $65 \%$ methane $\left(\mathrm{CH}_{4}\right)$ and $35 \%$ carbon dioxide $\left(\mathrm{CO}_{2}\right)$ saturated with water. It is also an efficient way of waste water treatment and renewable energy production. Using renewable energy resources such as biogas to replace fossil fuels closes the carbon cycle and thus reduces the amount of carbon dioxide in the atmosphere. It also inhibits formation of acid rain by reducing the amount of pollutants in the atmosphere [3].

Biogas is a combustible gas consisting of methane, carbon-dioxide, and small traces of hydrogen-sulphide, ammonia, nitrogen, and hydrogen [4]. The calorific value of biogas is about $6 \mathrm{kWh} / \mathrm{m}^{3}$ which corresponds to the value about half a litre of Diesel oil can give [5]. The net calorific value depends on the efficiency of the burners or appliances. Methane is the major component of biogas being used as a fuel. If properly harnessed biogas can be utilised for meeting rural energy needs as a biomass technology which is an alternative energy method. Cattle dung and agricultural wastes are available which can be used in the production of biogas in our rural areas [6].

A comparative study was carried out on biogas production for 30 days from Cow dung, Cow Pea and cassava peeling mixed with water using 45 litres biogas digester and found that cow dung produced a better yield of biogas [2]. A similar work has been by comparing biogas production using cassava peels blended with pig dung and using pig dung only in a metallic bio-digester for 30 days and found that the cassava peels blended with pig dung has a better yield of biogas than pig dung alone [7]. There is need to develop efficient and ready-to-access methods of providing domestic energy using small-scale biogas digester that would be safe to handle. Such biogas digester method would improve sanitation in rural communities, as well as providing high economic and environmental benefits to the end users [8].

\section{A. Biogas Digesters}

The biogas digester could be described as a structure, usually referred to as the biogas plant in which different chemical and microbiological reactions occur. In another 
word, it is called bioreactor or anaerobic reactor of which primary function is to provide within it an anaerobic condition. It is a chamber that should be air and water tight. Diverse materials could be used in fabricating the digester chamber in different sizes and patterns. It is important to note that the investment costs for a biogas plant consists mainly of the cost of constructing the digester chamber [9]. There are three main types of biogas plants: floating drum type, fixed dome type, balloon type [10].

\section{B. Floating Drum Type}

The floating drum design consists of the digester chamber made of brick masonry in cement mortar. In order to collect the biogas produced from the digester, a mild steel drum is mounted on the digester. This arrangement results in two separate structures for gas production and collection. The merits of this design include: constant gas pressure; the gasholder rises above the digester pit clearly show that gas is available. The demerits include: high cost of using mild steel to construct gas holder drum, and high maintenance cost [9].

\section{Fixed Dome Type}

The fixed dome was developed and built in China in 1936 and it is usually referred to as Chinese's model biogas plant. It is made up of an underground brick masonry fermentation chamber having a dome positioned on top to be used as gas storage. In this design, the fermentation chamber also function as the gas holder unit. Mild steel is not used to construct the gas holder in this design thereby making it less expensive and not prone to corrosion. Fixed dome type plant lasts longer than the floating drum type [11].

\section{Balloon Type}

The most commonly used low cost plant is called the Plastic Bag Digester. A digester bag made of polyvinyl chloride constitutes the balloon plant. The bag in which the gas is stored is placed on top. The plastic skin of the balloon is fitted to the inlet and outlet. The elasticity of the balloon results in the gas pressure. Additional weights are also placed on the balloon to contribute to the gas pressure. It is mainly made up of the following major parts: digester, gas holding, dung inlet, slurry outlet and gas outlet pipe [12].

\section{E. Pressure Vessel Design}

Vessels, tanks, and pipelines that carry, store, or receive fluids are called pressure vessels. A pressure vessel is defined as a container with a pressure differential between inside and outside [13]. A pressure vessel design problems was solved using ASME section viii division 1 code by using the following steps: selection of material, calculating the sizes, calculating thickness of the cylindrical shell, calculating pressure for the cylindrical shell, calculating thickness and pressure for hemispherical shell, and calculating the dimensions of legs and support [14].

Pressure vessels are categorized as either thin shell (thin walled) or thick walled. Pressure vessels are termed thin shell if the ratio of the inner radius to the wall thickness of the pressure vessel are greater than or equal to 10 , otherwise, they are termed thick walled [14].

\section{F. Temperature inside the Digester}

Production of high quantity and quality of biogas depends very much on the choice of temperature and control. Similarly, the entire anaerobic digestion process depends on temperature and control choice.

Some microorganisms are stimulated in a high temperature medium while others are stimulated in a low temperature reaction medium. For instance, the group called mesophilic bacteria require low temperature of about $35^{\circ} \mathrm{C}$, and the thermophilic bacteria require relatively higher temperature of about $55^{\circ} \mathrm{C}$. This trends induce various degrees of biodegradability of organic materials. Temperature of about $55^{\circ} \mathrm{C}$ is about the maximum any bacteria could be stimulated to function. Hence, temperature influences greatly the quantity and quality of biogas production [15].

\section{G. Pressure inside the Digester}

Biogas production, pressure is of great significance to be conceded, Nikolić experiments have shown that when hydrostatic pressure in which the operating methanogenic bacteria increase over 400 - $500 \mathrm{~mm} \mathrm{H}_{2} \mathrm{O}$, biogas production ceases [15].

\section{H. The Modifications}

Having critically studied the three types biogas digesters mentioned; this work will modify the following areas of interest in order to achieve desired goals:

i. Floating drum in the area of gas generation and collection. The floating drum has a fixed mild steel drum placed on top of the digester to collect all gas produced from the digester, but this work will modified it to have three movable vessels. Also, the fixed digester chamber made of bricks masonry in cement mortar will be modified to a movable vessel made of steel for portability.

ii. Flexible balloon in the area of gas pressure increase and storage. The flexible balloon consists of a digester bag (e.g. PVC) in the upper parts for gas storage. The gas pressure is achieved by placing weights on the balloon, which has its limitations as mentioned, but this work will also improve on it by using a further modified bike pump to eliminate the limitations and increase the pressure to suite modern day movable cylinder demand.

The vessels used in this work will be design in accordance with ASME Boiler and Pressure Vessel Code in 1914. If the ratio of the inner radius and the wall thickness of the pressure vessel are greater than or equal to 10 , then it is called a thin shell or thin walled pressure vessel or it will be a thick walled one [14]. This will also be mentioned in the cause of this work.

The main aim of this research was to design and fabricate a portable biogas digester to suit modern requirements of dimension, portability, improved efficiency and safety. In doing so, the following tasks were carried out, namely, design and fabrication of a gas collector; design and fabrication of a portable gas storage tank; incorporating safety and control measures; and introducing a devise to increase pressure and velocity of the biogas produced to suit modern gas cookers design.

Biogas digesters available in the market are bigger in size, commonly used for the fermentation of waste products to produce methane gas. In this research, the biogas digester 
was designed fabricated in smaller dimension; bike pump was selected and modified as a device to boost gas pressure and velocity.

\section{MATERIALS AND METHODS}

\section{A. Materials}

$17 \mathrm{~kg}$ of cow dung and $34 \mathrm{~kg}$ of water were the raw materials used for this research. Fresh cow dung was collected from the slaughter house, in Port Harcourt. Other materials are AISI 304 (Chromium-Nickel steel) for the vessel shells and the maximum allowable stress is $137 \mathrm{MPa}$. A $0.076 \mathrm{~mm}$ and $12.7 \mathrm{~mm}$ diameter ball valve, fire detector, relieve valve and pressure gauges are also used, its dimensions/positioning are carefully selected arbitrary after much comparison to that of liquid filed natural gas cylinders found in most homes around the country.

A bike pump is modified and used to increase methane gas pressure to suit the modern day gas cookers design and storage tank while an electronic smoke alarm detector (model: Ei100) will be used for effective fire protection.

\section{B. Methods}

The cumulative volume of 124.3 litres of biogas produced within the period of 30 days and also the temperature of $32^{\circ} \mathrm{C}$ were adopted from the comparative study of [2]. Pressure of $4903.325 \mathrm{~Pa}$ were also adopted to be the maximum digester temperature [15].

This portable digester is designed as a vertical thin shell pressure vessel; if the ratio of the inner radius and the wall thickness of the pressure vessel are greater than or equal to 10, ( $\left.\frac{r}{t} \geq 10\right)$. The biogas digester is designed as a thin walled pressure vessel with radius-thickness ratio $\left(\frac{r}{t}\right)$ greater than 10 .

$\left(\frac{r}{t}\right)>10$

where $\mathrm{r}=$ Radius $(\mathrm{mm}), \mathrm{t}=$ Thickness $(\mathrm{mm})$.

\section{1) Pressure Vessel Sizing Equations}

A simple basic geometry formula is used to determine the height of the pressure vessel.

$\mathrm{V}=\pi \mathrm{r}^{2} \mathrm{~h}+\frac{4}{3} \pi \mathrm{r}^{3}$

where $\mathrm{h}=$ Straight height $(\mathrm{mm}), \mathrm{V}=$ Volume $\left(\mathrm{m}^{3}\right)$

The straight height obtained will be used as input for the AMSE section eight division one equations.

\section{2) Thickness Calculation for the Cylindrical Shell}

The ASME Section Eight Division one provides two equations for calculating the thickness of the cylindrical shell for the thin walled pressure vessel;

i. The minimum required thickness at the longitudinal seam welds

$$
\mathrm{t}_{\mathrm{a}}=\frac{\mathrm{PR} i 1}{(\mathrm{SE}-0.6 \mathrm{P})}
$$

ii. The minimum required thickness at the circular seam welds

$$
\mathrm{t}_{\mathrm{b}}=\frac{\mathrm{PR} i 1}{(2 \mathrm{SE}+0.4 \mathrm{P})}
$$

and, the minimum required design thickness for the vessel shell will be

$t_{r}=$ Maximum of $\left(\right.$ ta or $\left.t_{b}\right)+c$

where

$\mathrm{P}=$ Internal Pressure $\left(\mathrm{P}_{\mathrm{a}}\right)$

$\mathrm{R}_{i}=$ Inside radius of the thin walled pressure vessel (mm)

$\mathrm{c}=$ Corrosion allowance $(\mathrm{mm})$

$\mathrm{R}_{i 1}=$ Radius after adjusting the corrosion allowance (mm)

$\mathrm{R} i 1=\mathrm{R}_{i}-\mathrm{c}$

$\mathrm{E}=$ Weld efficiency of the seams $(\%)$

$\mathrm{S}=$ Allowable stress $(\mathrm{MPa})$

This conditions must be met $\left(t>t_{r}\right)$ in other for the assumed shell thickness to be safe.

3) Maximum Allowable Pressure Calculation for the Cylindrical Shell

To know the maximum allowable pressure for the thin walled vessels are very important in pressure vessel design. According to American Society of Mechanical Engineers Standard (ASME) Section eight Division one, the below equations are required;

i Longitudinal pressure applied to vessel shell.

$$
\mathrm{P}_{1}=\frac{\text { SEnt }}{(\mathrm{R} i 1+0.6 \mathrm{nt})}
$$

ii Circular pressure applied to vessel shell.

$$
\mathrm{P}_{2}=\frac{\text { 2SEnt }}{(\text { Ri1-0.4nt })}
$$

where $\mathrm{nt}=$ normal thickness of shell $(\mathrm{mm})$

$\mathrm{nt}=\mathrm{t}-\mathrm{C}$

ASME section 8 division 1 guidelines say that; Maximum allowable pressure inside the vessel, $\mathrm{Pm}=$ Minimum of $(\mathrm{P} 1$, $\mathrm{P} 2)$. The actual working pressure must be less than maximum allowable pressure calculated for the pressure vessel to be safe. $\mathrm{P}<=\mathrm{P}_{\mathrm{m}}$.

\section{4) Calculation for Hemispherical Shell}

The minimum required thickness and maximum allowable pressure of the storage tank hemisphere is also required. According to ASME section eight division one code, the following equations are necessary;

i. The minimum required thickness for hemispherical head of vessel.

$$
\mathrm{t}_{\mathrm{r} 1}=\frac{\mathrm{PR} i 1}{(2 \mathrm{SE}-0.4 \mathrm{P})}+\mathrm{c}
$$

ii. The maximum allowed pressure for hemispherical head of vessel.

$$
\mathrm{P}_{\mathrm{m} 1}=\frac{2 \text { SEnt }}{(\text { Ri1-0.4nt })}
$$


The American Society of Mechanical Engineering Standard Sec. 8 div. 1 suggested that the thin wall pressure vessel design is safe if;

iii. Actual shell thickness at the hemispherical portions

$$
\text { (t) } \geq \mathrm{t}_{\mathrm{r} 1}
$$$$
\text { iv. } \quad \mathrm{P} \leq \mathrm{P}_{\mathrm{ml}}
$$

\section{5) Design Concept of Pump}

To increase pressure and velocity of the biogas gas produce to suit the modern day gas cooker's design, a pump must be selected and included into the design. Safety, cost, accessibility, lifespan and efficiency are the key element considered while choosing a pump. Cost, safety and accessibility are the major determinants on the pump selection. Lifespan and efficiency are also important, but high lifespan and efficiency are associated with pumps that have high costs, which is not the case with this project. The modified bike pump was chosen as the best option because it's cost is quite low, it's level of safe usage is high it's efficiency and life-span are moderate, and it is easily accessible [16].

\section{6) The Compressing Mechanism}

The modified bike pump was tested and found to be suitable for the compressing mechanism in which an inclined "foot pump" mechanism and a relatively large cylinder were incorporated.

In the pump design one cylinder is supported to stand vertically with the support of a simple A-frame. The pump design also include a long lever arm which the operator will handle to operate the pump, thereby, hands to control the system [16].

The heavy cylinder is kept relatively unmovable and it is made more stable and require less human force than having the cylinder itself moved with the lever. A pin is used to attach each plunger to the handle around which it rotates. This design enables the long lever arm acts in such a way as to make it easy for the plunger to move through the body of the cylinder. On-off control valves are fitted to the cylinder to regulate flow of gas. This will ensure that gas does not flow in and out of the pump simultaneously. This also serve as a safety measure for the compression process. Air is circulated in and out of the cylinder without creating a vacuum with each stroke of the plunger, and this makes pumping very easy. Compressed biogas in system moves through the outlet one-way valve connected to the storage tank. Basic half-inch brass swing valves are selected to form the one-way valves because they can operate under very low initial pressures of operation. The valves also have a relatively long life-span, and are relatively cheap [16].

Cylinder volume $\mathrm{V}=\pi r^{2} \mathrm{~h}$

where $\mathrm{V}=$ Volume $\left(\mathrm{m}^{3}\right), \mathrm{h}=$ height $(\mathrm{mm})$. Stroke rate:

1 stroke in 3 seconds $=100$ strokes in 5 minutes [16]

\section{7) Pump Lever Arm Analysis}

A lever amplifies an input force to provide a greater output force, which is said to provide leverages. The ratio of the output force to the input force is the mechanical advantage of the lever.

$\mathrm{MA}=\frac{W}{\mathrm{~F}}$
Three classes of Levers are identified based on the positions of the fulcrum, input and output forces. The classes are first class, second class and third class. First class levers are those having the fulcrum in the middle, effort is applied on one side and load on the other end. Second class levers are those types having the load in between the effort and the fulcrum. Third class levers are levers having the effort in between the load and the fulcrum [17].

$\mathrm{F} \times \mathrm{L}=\mathrm{W} \times \chi$

$\mathrm{MA}=\frac{L}{\chi}$

where;

$\mathrm{F}$ is the amount of force available in newton $(\mathrm{N})$

$\mathrm{L}$ is length to fulcrum in meter (m)

$\mathrm{W}$ is the actual force in newton $(\mathrm{N})$

$\chi$ is Length of the equilibrium in meter $(\mathrm{m})$

MA is Mechanical Advantage (m)

8) Pump Discharge and Power Input

Pump discharge $(Q)=\frac{A L N}{60} \mathrm{~m}^{3} / \mathrm{s}$

Power input $(P)=\frac{\dot{\rho} g h Q}{\eta} \mathrm{kW}$

where $\mathrm{Q}=$ Discharge through pump per second, $\mathrm{A}=$ Cross section area, $\mathrm{r}=$ Crank radius, $\mathrm{N}=$ rpm of the crank,

$\mathrm{L}=$ Stroke Length, $\mathrm{h}=$ head of pump, $\mathrm{g}=$ Gravitational constant, $\dot{\rho}=$ Density of fluid biogas, $\eta=$ pump efficiency $\mathrm{A}=0.00062 \mathrm{~m}^{2}, \mathrm{Q}=0.00019 \mathrm{~m}^{3} / \mathrm{s}$,

Power input $(P)=\frac{\dot{\rho} g h Q}{\eta} \mathrm{kW}$

$\grave{\rho}=1.15 \mathrm{~kg} / \mathrm{m}^{3}, \eta=85 \%=0.085, P=0.00077 \mathrm{~kW}$.

\section{9) Basic Design Model}

The material balance for continuous flow anaerobic digester can be established on the basis of the continuous stirred Tale Barometer (CSTR) material balance for substrate (Acid-forming) bacteria. The mathematical expression for inflow and substrate utilization is given as

$\mathrm{Vd} X_{a}=\mathrm{F} X_{a}^{0} d t-\mathrm{F} X_{a}^{s} d t+\left(R_{g 2}+R_{g 3}\right) V-\left(R_{g 2}+R_{g 3}\right)$

where $R_{g 2}, R_{g 3}, R_{d 2}, R_{d 3}$ are reaction rates, $X_{a}^{0}$ and $X_{a}^{s}$ are biomass cone $(\mathrm{g} / \mathrm{\ell}), \mathrm{V}$ is volume of reaction $\left(\mathrm{m}^{3}\right), \mathrm{F}$ is the feed flow ( $\mathrm{m}^{3} /$ day)

Assuming the decay rate is given as

$$
\begin{aligned}
& R_{g 2}=\mu_{2} X_{a} \\
& R_{g 3}=\mu_{3} X_{a} \\
& R_{d 2}=\mathrm{d}_{2} X_{a} \\
& R_{d 3}=\mathrm{d}_{3} X_{a}
\end{aligned}
$$

Substituting (20) and (21) into (19) 
$\frac{d X a}{d t}=\frac{F}{V}\left(X_{a}^{0}-X_{a}\right)+\mu_{2} X_{a}+\mu_{3} X_{a}-\mathrm{d}_{2} X_{a}-\mathrm{d}_{3} X_{a}$

Let $D=\frac{F}{V}=$ dilution rate $\left(\frac{L}{m}\right)$, Assuming

$\mu_{2}+\mu_{3}-d_{2}-d_{3}=\mu_{a}$

Thus $\frac{\mathrm{d} X \mathrm{a}}{\mathrm{dt}}=D\left(X_{a}^{0}-X_{a}\right)+\mu_{a} X_{a}$

at steady state condition (25) becomes

$\theta_{n} \mu_{a} X_{a}=\left(X_{a}-X_{a}^{0}\right)$

where $\theta_{\mathrm{n}}$ is hydraulic retention time, is specific growth rate (fu/day), d is microbial decay rate (n/day). But;

$\mathrm{D}=\frac{1}{\theta_{n}}=\frac{\mu_{2} X_{a}}{\mathrm{Xa}-X_{a}^{0}}$

\section{0) Material Balance for Biodegradables}

Similarly, a material balance for the biodegradable in terms of inflow, outflow and utilization is expressed as

$V d\left[H_{b}\right]=F\left[H_{b 0}\right] d \mathrm{t}-F\left[H_{b}\right] d \mathrm{t}+\left(R_{s}\right) \mathrm{V}$

The turnover rate unit volume $\left(R_{S}\right)$ is defined as

$$
R_{s}=K_{a}\left[H_{b}\right] X_{a}
$$

Substituting (29) into (28) and on simplification;

$\frac{d\left[H_{b}\right]}{d t}=D\left(\left[H_{b 0}\right]-\left[H_{b}\right]\right)-K_{s}\left[H_{b}\right] X_{a}$

At steady state:

$\frac{d\left[H_{b}\right]}{d t}=0$

Therefore, (31) can be re-arranged as:

$\theta_{n} \mathrm{~K}_{s}\left[H_{b}\right] X_{a}=\left(\left[H_{b 0}\right]-\left[H_{b}\right]\right)$

where $\left[\mathrm{H}_{\mathrm{b}}\right]$ and $\left[\mathrm{H}_{\mathrm{bo}}\right]$ are initial and final substrate concentration $\left(\mathrm{kg} / \mathrm{m}^{3}\right)$, Ks is the Monod constant or dissociation constant, therefore

$\theta_{n}=\frac{\left[H_{b 0}\right]-\left[H_{b}\right]}{K\left[H_{b}\right] X_{a}}=\frac{1}{\mathrm{~K}_{s} X_{a}}\left(\frac{\left[H_{b 0}\right]}{\left[H_{b}\right]}-1\right)$

Equating (26) and (33) we have

$\theta_{n}=\frac{X_{a}-X_{a}^{0}}{\mu_{2} X_{a}}=\frac{1}{\mathrm{~K}_{s} X_{a}}\left(\frac{\left[H_{b 0}\right]}{\left[H_{b}\right]}-1\right)$

Therefore

$X_{a}=X_{a}^{0}+\frac{\mu_{0}}{\mathrm{~K}_{s}}\left(\frac{\left[H_{b 0}\right]}{\left[H_{b}\right]}-1\right)$

Substituting (35) into (26) yields

$\theta_{n}=\frac{1}{\mu_{0}}\left[1-\frac{K_{S}-X_{a}}{K_{S}-X_{a}^{0}+\mu_{a}\left[\frac{\left[H_{b 0}\right]}{\left[H_{b}\right]}\right]}\right]$ c) Reactor Operating Parameters:

Let;

$\alpha=\frac{\left[H_{b 0}\right]-\left[H_{b}\right]}{\left[H_{b}\right]}=1-\frac{\left[H_{b}\right]}{\left[H_{b o}\right]}$

where, $\alpha$ is fractional conversion in (\%) (37) can be presented as

$\theta_{n}=\frac{1}{\mu_{a}}\left[1-\frac{K_{a}-X_{a}^{0}}{K_{S} X_{a}^{0}+\mu_{[1-\alpha]}^{[\alpha]}-1}\right]$

\section{1) Reactor Dimension \\ a) Reactor Volume:}

Digesters may be designed on the basic of the organic loading or the mean cell residence fine. Since the process is not an activated sludge system. The mean cell residence fine is the same as the retention fine, consequence the volume of the digesters is given as:

$V_{R}=Q \theta_{c}-\theta_{n}$

where $\boldsymbol{\theta}_{\mathrm{c}}$ is mean solid retention (day) fresh sludge substituting (39) in (40), the above equation yields.

$V_{R}=\left\{Q \frac{1}{\mu}\left[1-\frac{K_{s}-X_{a}^{0}}{K_{S} X_{a}^{0}+\mu_{a} \frac{[\alpha]}{[1-\alpha]}-1}\right]\right\}$ or $\left\{\frac{Q}{\mu_{a}}\left[1-\frac{K_{s}-X_{a}^{0}}{\left.K_{S} X_{a}^{0}+\mu_{a} \frac{[\alpha]}{[1-\alpha]}\right]}\right]\right\}$

b) Diameter of Reactor:

The volume of the reaction can be presented as

$V_{R}=A_{R} H_{R}$

Taking the height $H_{R}$ as twice the reactor diameter hence (41) becomes

$V_{R}=\frac{\pi D_{R}^{2}}{4} 2 D_{R}$

Where; $\quad V_{R}=\frac{\pi D_{R}^{3}}{2} 2 D_{R}$

$D_{R}^{3}=\frac{2 V_{R}^{2}}{\pi}$

Therefore;

$D_{R}=\left[\frac{2 V_{R}}{\pi}\right]^{1 / 3}$

Substituting for $V_{R}$ in the above equation gives

$D_{R}=\frac{2 Q}{\pi \mu_{a}}\left[1-\frac{K_{S} X_{a}^{0}}{K_{S} X_{a}^{0}+\mu_{a}[\alpha]}\right]$

\section{(1) Hydraulic Retention Time}

The hydraulic retention time affects the extend of substance removal, as well as plant cost and can be presented mathematically from (40) thus; 
$\theta_{n}=\frac{V_{R}}{Q}$

From equation (42);

$\theta_{n}=\frac{1}{\mu_{a}}\left[1-\frac{K_{S}-X_{a}^{0}}{K_{S} X_{a}^{0}+\mu_{a} \frac{[\alpha]}{[1-\alpha]}}\right]$

\section{(2) Volumetric Organic Loading Rate}

The volumetric organic loading rate is expressed mathematically as:

$V a_{/ r}=\frac{\left[H_{0}\right]}{\theta_{n}}$

Combining (49) and (50)

$V a / r=\frac{\left[H_{0}\right]}{\left\{\frac{1}{\mu_{a}}\left[1-\frac{K_{S} X_{a}^{0}}{\left.K_{S} X_{a}^{0}+\mu_{a} \frac{[\alpha]}{[1-\alpha]}\right]}\right]\right\}}$

\section{RESULTS AND DISCUSSION}

Some requirements involved extensive calculations to predict whether the specification would be met. The research also produced a cumulative gas volume of $0.055 \mathrm{~m}^{3}$ for 12 days. An intensive work has been done using the American Society of Mechanical Engineering standards and codes to determine, to an extent, the height of digester, collector and storage tank to be $\mathrm{h}=1.05 \mathrm{~m}, 0.6 \mathrm{~m}$ and $1.6 \mathrm{~m}$ respectively. The minimum required design thickness for the vessel shell $\mathrm{t}_{\mathrm{r}}=0.0267 \mathrm{~mm}, 0.025 \mathrm{~mm}$ and $0.0204 \mathrm{~mm}$ for digester, collector and storage tank respectively. Maximum allowable pressure inside the vessel, $\mathrm{P}_{\mathrm{m}}=3.55 \mathrm{MPa}, 4.69$ $\mathrm{MPa}$ and 4.23 $\mathrm{MPa}$ for digester, collector and storage tank respectively. As the final step, series of test were carried out to ensure that the constructed prototype met the required specifications.

\section{A. Methods Design Analysis and Fabrications}

The summary of digester, gas collector, and storage tank sizing and design parameters obtained using ASME codes and standards are presented in Table I.

TABLE I: SUMMARY OF (ASME) CODE CALCULATIONS AND RESUlTS OBTAINED

\begin{tabular}{lcc}
\hline \hline ASME Calculations & Values & Units \\
\hline $\begin{array}{l}\text { Digester height } \\
\begin{array}{l}\text { Digester minimum thickness at the longitudinal } \\
\text { seam welds }\end{array}\end{array}$ & 0.0067 .76691 & $\mathrm{Mm}$ \\
$\begin{array}{l}\text { Digester minimum thickness at the circular seam } \\
\text { welds }\end{array}$ & 0.003359539 & $\mathrm{Mm}$ \\
$\begin{array}{l}\text { Minimum required digester thickness for the } \\
\text { vessel shell }\end{array}$ & 0.026719379 & $\mathrm{Mm}$ \\
$\begin{array}{l}\text { Digester Internal pressure } \\
\text { Longitudinal pressure applied to the digester } \\
\text { vessel shell }\end{array}$ & 0.004903 & $\mathrm{MPa}$ \\
$\begin{array}{l}\text { Circular pressure applied to the digester vessel } \\
\text { shell }\end{array}$ & 7.54562976 & $\mathrm{MPa}$ \\
$\begin{array}{l}\text { Collector straight height } \\
\text { Collector minimum thickness at the longitudinal } \\
\text { seam welds }\end{array}$ & 0.005039254 & $\mathrm{Mm}$ \\
$\begin{array}{l}\text { Collector minimum thickness at the circular } \\
\text { seam welds }\end{array}$ & 0.002519514 & $\mathrm{Mm}$ \\
$\begin{array}{l}\text { Minimum required collector thickness for the } \\
\text { vessel shell }\end{array}$ & 0.02503925 & $\mathrm{Mm}$
\end{tabular}

\begin{tabular}{|c|c|c|}
\hline Collector Internal pressure & 0.004903325 & $\mathrm{MPa}$ \\
\hline $\begin{array}{l}\text { Longitudinal pressure applied to the collector } \\
\text { vessel shell }\end{array}$ & 4.68977498 & $\mathrm{MPa}$ \\
\hline $\begin{array}{l}\text { Circular pressure applied to the collector vessel } \\
\text { shell }\end{array}$ & 9.9104196 & $\mathrm{MPa}$ \\
\hline Storage tank straight height & 1617.37105 & $\mathrm{Mm}$ \\
\hline $\begin{array}{l}\text { Storage tank minimum thickness at longitudinal } \\
\text { seam welds }\end{array}$ & 0.0003949154 & $\mathrm{Mm}$ \\
\hline $\begin{array}{l}\text { Storage tank minimum thickness at circular seam } \\
\text { welds }\end{array}$ & 0.0001968357 & $\mathrm{Mm}$ \\
\hline $\begin{array}{l}\text { Minimum required tank thickness for the vessel } \\
\text { shel }\end{array}$ & 0.0203949154 & $\mathrm{Mm}$ \\
\hline Storage tank Internal pressure & 0.345 & MPa \\
\hline $\begin{array}{l}\text { Longitudinal pressure applied to the storage tank } \\
\text { vessel shell }\end{array}$ & 4.23431552 & $\mathrm{MPa}$ \\
\hline $\begin{array}{l}\text { Circular pressure applied to the storage tank } \\
\text { vessel shell }\end{array}$ & 8.89902845 & $\mathrm{MPa}$ \\
\hline $\begin{array}{l}\text { Maximum allowable pressure inside the storage } \\
\text { tank vessel }\end{array}$ & 4.23431552 & $\mathrm{MPa}$ \\
\hline $\begin{array}{l}\text { Minimum required thickness for hemispherical } \\
\text { head of the storage pressure vessel tank }\end{array}$ & 0.2170685 & $\mathrm{Mm}$ \\
\hline $\begin{array}{l}\text { Maximum allowed pressure for hemispherical } \\
\text { head of the storage pressure vessel tank }\end{array}$ & 8.89902845 & $\mathrm{MPa}$ \\
\hline
\end{tabular}

\section{B. Bio-digester Fabrication}

The bio-digester is fabricated in smaller dimension; the size is carefully calculated and selected after much comparison to that of liquefied petroleum gas cylinders.

The following are the processes involved in the fabrication of the bio-digester shown in Fig. 1:

i. A $1000 \mathrm{~mm}$ length of pipe is cut off from $240 \mathrm{~mm}$ diameter AISI 304 SS steel.

ii. Holes are drilled at $50 \mathrm{~mm}, 700 \mathrm{~mm}$ and $870 \mathrm{~mm}$ and the sizes are $12.7 \mathrm{~mm}, 25.7 \mathrm{~mm}$ and $50.8 \mathrm{~mm}$

iii. Weld tap-off port, stirrer handle and $50 \mathrm{~mm}$ ball valve

iv. $\quad \Theta 360 \mathrm{~mm}$ was neatly cut off from a $5 \mathrm{~mm}$ gauge AISI 304 SS steel plate.

v. $\quad 8$ holes were drilled for bolts and $\Theta 76 \mathrm{~mm}$ for 76 mm ball valve.

vi. All the parts were together assembled

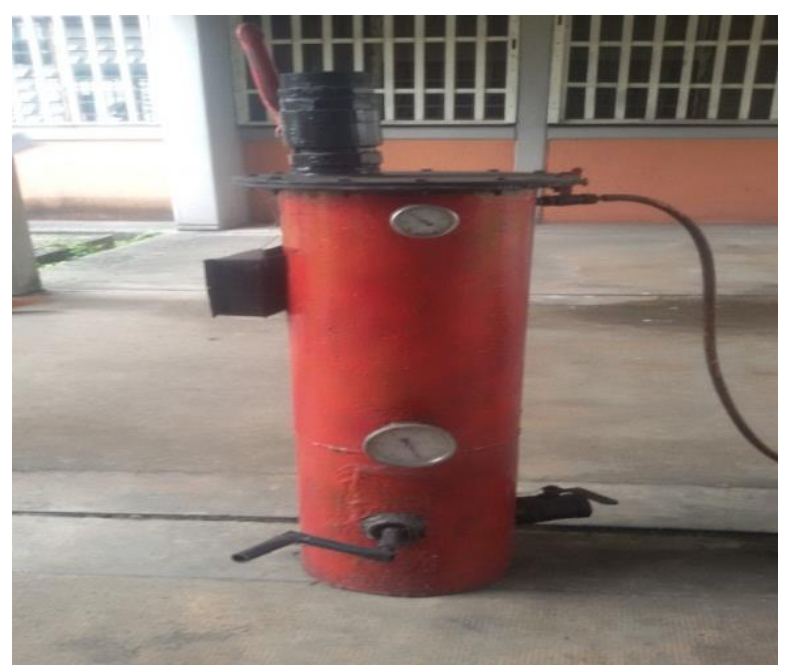

Fig. 1. Pictorial view of fabricated digester

\section{Gas Collector Fabrication}

The gas collector shown in Fig. 2 is fabricated in smaller dimension. The following are the processes involved in the fabrication of the biogas collector:

i A $600 \mathrm{~mm}$ length of pipe is cut off from $180 \mathrm{~mm}$ diameter AISI 304 SS steel. 
ii Holes are drilled at $20 \mathrm{~mm}$ from top and bottom and the sizes are $\Theta 12.7 \mathrm{~mm}$,

iii $12.7 \mathrm{~mm}$ ball valve is threaded to the drilled hole for isolation.

iv $130 \mathrm{~mm} \times 130 \mathrm{~mm}$ was neatly cut off from a $5 \mathrm{~mm}$ gauge AISI 304 SS steel plate

$\mathrm{v} \quad$ All the parts are together assembled

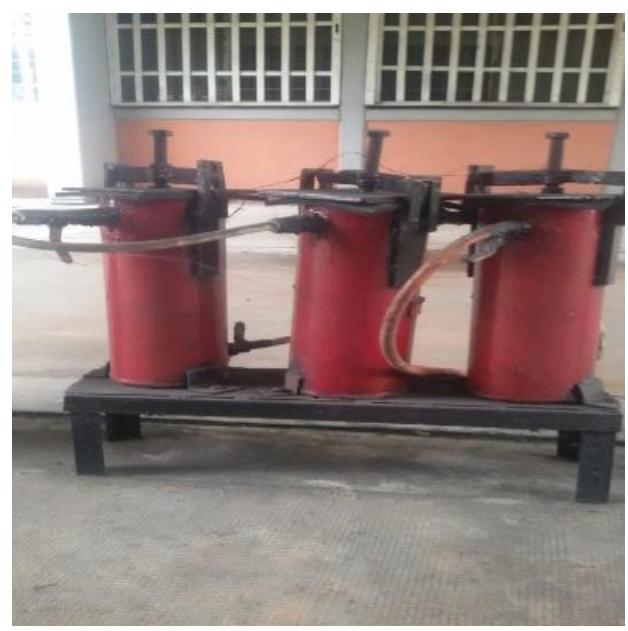

Fig. 2. Pictorial views of fabricated collectors

\section{Modified Hand Pump Fabrication}

The following are processes involved in the fabrication of modified hand pump shown in Fig. 3;

i $200 \mathrm{~mm} \times 25 \mathrm{~mm}$ was neatly cut off from a $5 \mathrm{~mm}$ gauge AISI 304 SS steel plate

ii $100 \mathrm{~mm}$ x $40 \mathrm{~mm}$ was neatly cut off from a $5 \mathrm{~mm}$ gauge AISI 304 SS steel plate

iii Holes were drilled on top and bottom of steel handle and lever link, $\Theta 12.7 \mathrm{~mm}$,

iv $100 \mathrm{~mm} \times$ Ө $25 \mathrm{~mm}$ was neatly cut off from wood.

v $300 \mathrm{~mm}$ x $180 \mathrm{~mm}$ was neatly cut off from a $5 \mathrm{~mm}$ gauge AISI 304 SS steel plate

vi All the parts were together assembled

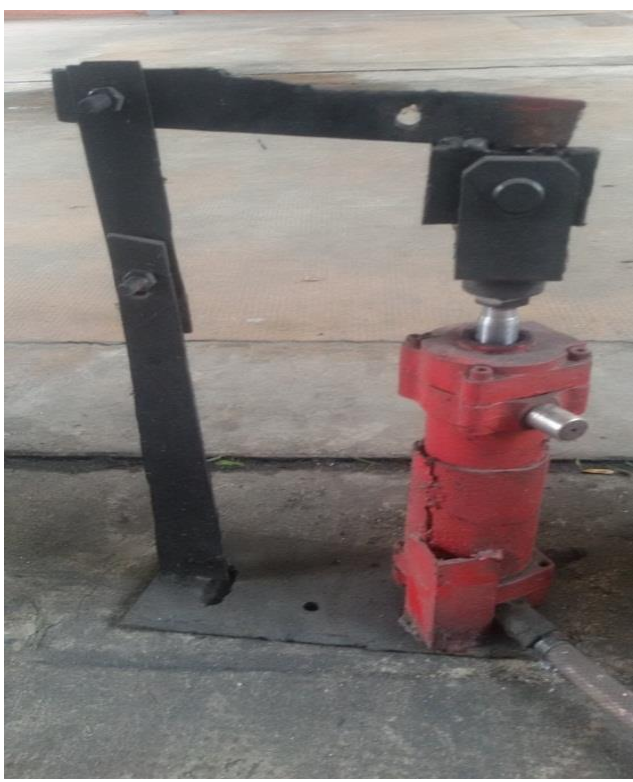

Fig. 3. Pictorial view of fabricated modified bike pump

\section{E. Safety and Control Measures}

Unlike other biogas plant, an electronic smoke alarm detector (model: Ei100) is placed $300 \mathrm{~mm}$ below the digester top for effective fire protection.

The electronic smoke alarm detector has the following features and functions;

i. Ionisation sensor: Responds to all fires and is especially responsive to fast flaming fires.

ii. It has loud alarm up to 85 decibels at three (3) metres.

iii. Test button simulates smoke.

iv. Powered by Battery

v. Warning bleep when battery needs replacement.

Pressure gauges of (0-2.5 barg) are installed on the biodigester and the storage tank for operator (user) to actually read gas pressure within the system to avoid explosion.

Relief valves, which is always the last barrier are installed and used in storage tank in case of over pressurisation. The excess gasses will be released out of the system.

\section{F. Assembling of Different Units Together}

This is achieved through an outlet gas pipe located near the top of the digester. The outlet pipe is a PVC pipe attached to a hose clamp. Although the outlet pipe size is not of great consequence, a converter barb is used to connect the digester to the $1.27 \mathrm{~cm}$ flexible PVC pipe. One end of the barb is $1.27 \mathrm{~cm}$; the other end of the pipe in connected to the digester. The PVC pipe is also used to connect the collector, pump and storage tank. The assembled units are presented in Fig. 4.

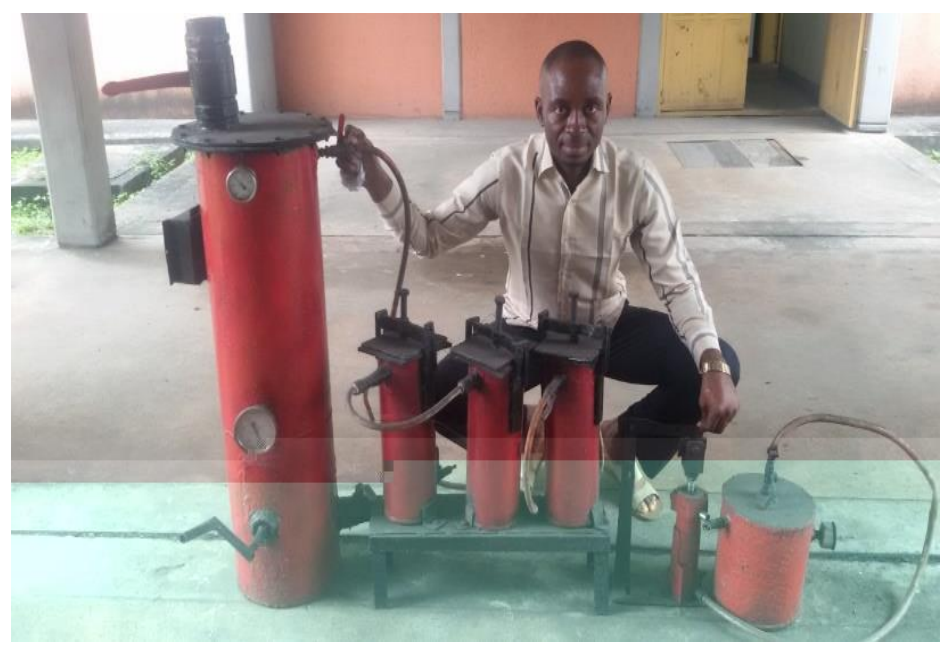

Fig. 4. Pictorial view of fabricated biodigester unit.

\section{G. Summary on Safety Result}

For digester and collectors;

i The shell thickness, $(\mathrm{t})=5 \mathrm{~mm}$ assumed initially and $t>t_{r}$ also assumed shell thickness is safe.

ii The digester is safe, because the initial pressure is lesser than the minimum calculated pressure. $\mathrm{P}<\mathrm{Pm}$

For storage tank;

i. Shell thickness, $(\mathrm{t})=5 \mathrm{~mm}$ was initially assumed. According to ASME section 8 division 1 guidelines, $\mathrm{t}$ $>\mathrm{t}_{\mathrm{r}}$. So, because $5 \mathrm{~mm}>0.02039 \mathrm{~mm}$, the assumed thickness is safe.

ii. Calculated shell thickness at the hemispherical portions $(0.22 \mathrm{~mm})$ is much lesser than the actual thickness $(5 \mathrm{~mm})$ and maximum allowable pressure for hemispherical head of the storage tank pressure 
vessel $\mathrm{P}_{\mathrm{ml}}(8.9 \mathrm{MPa})$ is larger than $\mathrm{P}(0.304 \mathrm{MPa})$, so this vessel design is acceptable according to the ASME design codes and is safe.

\section{H. Generating the Gas}

To generate biogas, biological wastes were crammed to gas-tight digester after the wastes have been proportionately mixed with water. In this case, cow dung was used. As fresh charge come in, some of the old charge are displaced and eliminated. It should not be forgotten that bio-methane is eight times less dense than air, thus any opening, no matter how small, all the gas would vent into the atmosphere. This is one of the challenges that were successfully dealt with by performing gas leakage tests using compressed air and soap bubbles in the whole system.

Collection of Generated Gas

After gas formation at the digesting part of the system, as indicated on the digester's pressure gauge, it is transferred through the PVC hose to the collector chamber through a control valve. The flow of gas from the digester (high pressure side) to collector (low pressure side) is operated by a globe valve.

\section{Compressing and Storing}

The bike pump intake and discharge is controlled by two check valves, at the accumulation of enough gas at the collector, the ball valve at its top is opened. When this is done, the handle of the pump is raised and dropped continuously as a way to compress the gas after the globe valve allowing flow into the storage cylinder. After a reasonable amount of strokes have been performed, the tank and collector valves are closed for further accumulation of gas and the process is repeated.

\section{J. Unit Test Run}

A test run was also carried out on the unit as shown in Table II.

TABLE II: TEST RUN CARRIED OUT ON UNIT

\begin{tabular}{|c|c|c|c|c|c|c|}
\hline Steps & Time & Unit & Event Carried Out. & $\begin{array}{l}\text { Time } \\
\text { duration }\end{array}$ & Observation & Comments \\
\hline 1 & 00:00 & Digester & $\begin{array}{l}17 \mathrm{~kg} \text { of cow dung to } 34 \mathrm{~kg} \text { of } \\
\text { water was add }\end{array}$ & 10 mins & $\begin{array}{l}\text { No tools are needed for the } \\
\text { operation. }\end{array}$ & It's easy. \\
\hline 2 & $00: 15$ & Digester & Turn the Stirrer Handle & 2 mins & $\begin{array}{l}\text { No tools are needed for the } \\
\text { operation. }\end{array}$ & It's easy. \\
\hline 3 & 4 days & Digester & Check for biogas presence & $2 \mathrm{sec}$ & Biogas starts producing. & Gas present \\
\hline 4 & $\begin{array}{l}10 \\
\text { days }\end{array}$ & $\begin{array}{l}\text { Digester } \\
\text { gauge }\end{array}$ & Checked the gauge & $2 \mathrm{sec}$ & The gauge rises. & $\begin{array}{l}\text { Constant check is on-going } \\
\text { now. }\end{array}$ \\
\hline 5 & $\begin{array}{l}15 \\
\text { days }\end{array}$ & $\begin{array}{l}\text { Digester } \\
\text { gauge }\end{array}$ & Checked the gauge & $2 \mathrm{sec}$ & The gauge rises than the early days. & $\begin{array}{l}\text { Constant check is still on- } \\
\text { going now. }\end{array}$ \\
\hline 6 & $\begin{array}{l}20 \\
\text { days }\end{array}$ & $\begin{array}{l}\text { Modified } \\
\text { bike pump }\end{array}$ & $\begin{array}{l}\text { Compress gas to the storage tank } \\
\text { starts, and is done whenever a } \\
\text { digester gauge rise to a reasonable } \\
\text { pressure. }\end{array}$ & 5 mins. & $\begin{array}{l}\text { The gauge of the digester drops and } \\
\text { that of the tank rise to. }\end{array}$ & $\begin{array}{l}\text { The rise in pressure gauge is } \\
\text { as a result of the bio-gas } \\
\text { compress to storage tank. }\end{array}$ \\
\hline 7 & $\begin{array}{l}20 \\
\text { days } \\
\text { to? }\end{array}$ & Gas burner & $\begin{array}{l}\text { Beans was cooked, twice ( } 50 \text { mins) } \\
\text { each } \\
\text { Rice was cooked, three times ( } 30 \\
\text { mins) each } \\
\text { Water was boiled five times } \\
\text { (average of } 10 \text { minutes) each } \\
\text { Soup was cooked ( } 120 \text { mins) } \\
\text { Stew were made ( } 90 \text { mins) }\end{array}$ & $\begin{array}{l}100 \text { mins } \\
90 \text { mins } \\
50 \text { mins } \\
120 \text { mins } \\
90 \text { mins }\end{array}$ & $\begin{array}{l}\text { Over the days, the gas produced is } \\
\text { enough to cook the meals with the } \\
\text { flame burning at pale blue colour. }\end{array}$ & \\
\hline
\end{tabular}

\section{CONCLUSION}

A portable biogas digester for renewable biogas production and storage has been designed and fabricated. In addition, the device has been tested to handle the production of biogas from cow dung at a volumetric rate of about $1.91 \times 10^{-4} \mathrm{~m}^{3} / \mathrm{hr}$. This resulted in a cumulative gas volume of about $0.055 \mathrm{~m}^{3}$ produced in 12 days.

One important feature that has been introduced is the compression of biogas before storage. Storage of produced biogas is very necessary because of its fluctuating nature. For continuous storing, the gas has to be compressed considerably. The compressor employed is one of simple fabrication and operation. In order to achieve this, the compressor was made to be manually operated by the application of a little force. The charging port has been intuitively machined such that fresh charge displaced older substrate by pushing it down and out through the discharge port. The ease of maintenance has also been ensured so that virtually everyone can operate the prototype.

The height of digester, collector and storage tank are 1.05 $\mathrm{m}, 0.6 \mathrm{~m}$ and $1.6 \mathrm{~m}$ respectively. The minimum required design thickness for the vessel shell, tr are $0.0267 \mathrm{~mm}$,
$0.025 \mathrm{~mm}$ and $0.0204 \mathrm{~mm}$ for digester, collector and storage tank respectively. The maximum allowable pressure inside the vessel, $\mathrm{Pm}$ are 3.55 $\mathrm{MPa}, 4.69 \mathrm{MPa}$ and $4.23 \mathrm{MPa}$ for digester, collector and storage tank respectively. A bike pump is employed to increase methane gas pressure from $4.903 \mathrm{kPa}$ to $345 \mathrm{KPa}$ to suit modern gas cookers and storage tank requirements. Furthermore, the pressure testing, gas leak test and the unit test run were all successful.

American Society of Mechanical Engineers (ASME) codes and standards were used to carry out the sizing, thickness and pressure calculations for the cylindrical pressure vessel, collector, and storage tank hemisphere shells. The adoption of the ASME codes and standards is to ensure that the design is acceptable and safe to operate at the approved limits of pressure.

It is worthy of note that raw materials (substrate) required for the production of biogas is in abundance in developing nations such as Nigeria. Hence, the introduction of this technology would be very much beneficial to low income countries owing to the renewable nature of the biogas resources. This waste-to-wealth as well as waste-to-energy technology would aid cheap household cooking with gas without paying extra cost of refilling petroleum gas. More so, this research has contributed in the areas such as 
demonstrating that biogas generation could be done in a kitchen without necessarily occupying so much space nor incurring further cost on petroleum gas; that biogas plant can be moveable from place to place to suit operator's ergonomics; and that biogas plant can also be erected like natural gas plants were advance pumping system would be employed to store gas in our usual home gas cylinders.

The authors would want to suggest the following further work to be done:

i. Further investigations should be done in the area of waste stream treatment.

ii. Further work should also be done on collector chamber because it could be used for gas scrubbing and cleaning if properly designed.

More detailed research can be performed on pump/compressor and storage tank design in order to obtain higher pressure values of the gas at the storage end as this would facilitate a higher mass of gas for a particular design volume of container.

\section{ACKNOWLEDGMENT}

The authors would want to thank the Department of Mechanical Engineering workshop and laboratory staff, Rivers State University for their guidance, comments, and permission to use all the appropriate machines in the laboratory and workshop. We also want to thank Dr. C.P. Ukpaka of the Department of Chemical/Petrochemical Engineering, Rivers State University for his assistance and useful comments offered in the course of carrying out this research. Besides, Mr. O.E. Nangi of the Department of Mechanical Engineering, Rivers State University is appreciated for his invariable contributions. Also, we thank Prof. O.M.I. Nwafor of Mechanical Engineering Department of Federal University of Technology, Owerri, for his corrective comments.

\section{REFERENCES}

[1] J.O. Babatola, "Comparative Study of Biogas Yield Pattern in Some Animal and Household Wastes", An International Multi-Disciplinary Journal, 2, 54-65, 2008.

[2] P.A. Ukpai, and M.N. Nnabuchi, Comparative Study of Biogas Production from Cow Dung, Cow Pea and Cassava Peels Using 45 Litres Biogas Digester. Department of Industrial Physics, Ebonyi State University Abakaliki: Pelagia Research Library, 2012. Available: www.pelagiaresarchlibrary.com

[3] A.C. Wilkie, "Anaerobic Digestion: Biology and Benefits", Diary Manure Management Conference: Treatment, Handling and Community Relations, NRAES-176, p63 - 72, Cornell University, Ithaca, NY, March $15 \quad-17$ 2005. Available: https://pdfs.semanticscholar.org/6bcc/933608cb6dd9e096e807cec4cb 15443f904d.pdf

[4] T. S. AlSeadi, R. Dominik, P. Heinz, K. Michael, F. Tobias, V. Silke, and J. Rainer, Biogas Handbook, University of Southern Denmark Esbjerg, Niels Bohrs Vej, 2008.

[5] ISAT - Information and Advisory Service on Appropriate Technology, Biogas Basics, Germany, 1999.

[6] R. Opeh, and U. Okezie, The Significance of Biogas Plants in Nigeria's Energy Strategy. Physical Sciences and Innovation. Department of Physics and Energy Studies, Western Delta University, Oghara: Cenresin Publications, 2011.

[7] N.F. Oparaku, A.C. Ofomatah, and E.C. Okoroigwe, Bio-Digestion of Cassava Peels with Pig Dung for Methane Generation, National Centre for Energy Research and Development, University of Nigeria Nsukka, Enugu State, Nigeria, 2013.

[8] V. Tumwesige, L. Avery, G. Austin, B. Balana, K. Bechtel, G. Zenk, and J. Smith, "Small-scale Biogas Digester for Sustainable Energy Production in Sub-Saharan Africa", 1st World Sustainability Forum, 1 30 Nov.,
http://www.biogasassociation.co.za/downloads/National\%20Research /National\%202.pdf; www.wsforum.org

[9] A. Daisy and S. Kamaraj, "The Impact and Treatment of Night Soil in Anaerobic Digester: A Review", Journal of Microbial \& Biochemical Technology, 3:043-050. DOI: 10.4172/19485948.1000050.Available: https://www.omicsonline.org/the-impactand-treatment-of-night-soil-in-anaerobic-digester-a-review-19485948.1000050.php?aid=1171

[10] L. Sasse, Biogas Plant, A Publication of the Deutsches Zentrum für Entwicklungstechnologien - GATE in: Deutsche Gesellschaft für Technische Zusammenarbeit (GTZ) GmbH - 1988. Available http://www.susana.org/_resources/documents/default/2-1799. biogasplants.pdf

[11] M. Kaoma, Potential Greenhouse Gas Emissions Reduction through Production and Utilization of Biogas from Pig Manure - Case Study for Zambia, A dissertation, Agricultural Engineering, School of Engineering, University of Zambia, Lusaka, 2013. Available: http://dspace.unza.zm:8080/xmlui/bitstream/handle/123456789/2070/ Dissertation\%20Mwansa\%20Kaoma.pdf?sequence=1

[12] Beenu and S. Sodhi, "Generation of Biogas energy and its uses", International Journal for Research in Applied Science \& Engineering Technology (IJRASET), Volume 4 Issue VIII, August 2016. Available: https://www.ijraset.com/fileserve.php?FID=5370

[13] B.S. Thakkar, and S.A. Thakkar, "Design of Pressure Vessel Using ASME Code, Section viii, Division one". International Journals of Advanced Engineering Research and Studies 1, 1-4, 2012

[14] G. Shibashis, Thin Walled Pressure Vessel Design Calculation Example to ASME section viii division 1, 2008. Available: http://blog.com/machine-design/simplified-asme-thin-wall-pressurevessel-design-calculation-example-part1-overview/

[15] D. Paul, N. Farcas, and M. Florentina, (2014). Main Factors Affecting Biogas Production - An Overview, University of Agronomic Sciences and Veterinary Medicine, Marasti, Romania, 2014.

[16] D. Baron, J. Leginski, A. Malek, T. Murphy and A. Smith, Biogas Compressor Project, ME450, Winter '08 Professor Skerlos, Section 6, Project 29 Department of Mechanical Engineering University of Michigan Ann Arbor, MI 48109-2125, 15 April, 2008. Available: https://deepblue.lib.umich.edu/bitstream/handle/2027.42/58672/?sequ ence $=1$.

[17] R. Kurtus, Three Lever Classes, School for Champions, 26 July, 2016. Available: https://www.school-forchampions.com/machines/levers_classess.htm\#.WqnM866nHIU

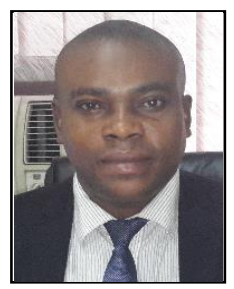

Barinyima Nkoi was born in Barayowa Dere in Gokana of Rivers State, Nigeria on 15th March, 1973. He obtained a Ph.D degree in Thermal power (Gas turbine engineering) from Cranfield University, Bedfordshire, United Kingdom, in 2015. He has Master of Technology (Thermo-fluid) and Bachelor of Technology degrees in Mechanical Engineering from Rivers State University, Port Harcourt, Nigeria in 2008 and 2000 respectively.

$\mathrm{He}$ is a former HEAD OF DEPARTMENT of Mechanical Engineering of Rivers State University, Port Harcourt, Nigeria where he started his teaching career as GRADUATE ASSISTANT in 2003 and rose to the rank of LECTURER till date. He has made the following paper publications among others:

B. Nkoi, K. Israel, and S. Adumene, "Performance analysis of an Energy System in the Tropical Rainforest: A Thermo-economic Approach", Journal of Power and Energy Engineering, 6, 8-20, 2018. https://doi.org/10.4236/jpee.2018.61002;

B. Nkoi, and T.E. Isaiah, "Advanced Cycles Large-scale Aero-derivative gas turbine: Performance Comparison" Journal of Power and Energy $\begin{array}{llll}\text { Engineering, } & \text { vol.4 } & \text { no.5 } & \text { 7-19, }\end{array}$ http://dx.doi.org/10.4236/jpee.2016.45002.; and

B. Nkoi, and B.T. Lebele-Alawa, "Comparative Assessment of Combinedheat-and-power Performance of Small-scale Aero-derivative gas turbine cycles", Journal of Power and Energy Engineering, 3, 20 - 32,2015. http://dx.doi.org/10.4236/jpee.2015.39002

Dr. Nkoi is a member of the following professional societies: Nigerian Society of Engineers (MNSE); American Society of Mechanical Engineers (ASME); Institution of Engineering and Technology (MIET), UK; Institution of Diesel and Gas Turbine Engineers (MIDGTE), UK; Registered/certified Mechanical Engineer of the Council for the Regulation of Engineering in Nigeria (COREN): Reg. No: 22421; CEng equivalent. 